\title{
GAYA KEPEMIMPINAN, LINGKUNGAN KERJA DAN SISTIM KOMPENSASI TERHADAP PRESTASI KERJA KARYAWAN PADA PT PURA SMART TECHNOLOGI
}

\author{
Daniel Grace Christiawan \\ Manajemen, Fakultas Ekonomi \\ STIE Semarang \\ e-mail : danielgrace@gmail.com \\ Rani Rahmayani \\ Manajemen, Fakultas Ekonomi \\ STIE YKP Yogyakarta
}

\begin{abstract}
The method used is research using a quantitative approach with descriptive research categories. In survey research, information is collected from respondents using a questionnaire. The population of this study were 40 employees as a sample, namely 40 employees. Testing the first hypothesis (H1) obtained tcount for the leadership style variable of 3.214 with a significance of 0.003 ( $p<0.05)$. The second hypothesis testing (H2) obtained tcount for the work environment variable of 2.566 with a significance of 0.015 ( $p<0.05)$. Testing the third hypothesis (H3) obtained tcount for the variable compensation system of 3,948 with a significance of 0,000 ( $p<0.05)$. The results showed that, (1) There is a positive influence of leadership style on employee work performance at PT Pura Smart Technology, which means that the higher or better the leadership style, the higher the employee's work performance, conversely the lower or worse the leadership style, the lower the achievement. employee work at PT Pura Smart Tecnology. The amount of the effective contribution of the leadership style to the work performance of employees at PT Pura Smart Technology is $22.7 \%$ and the relative contribution is $32.2 \%$. (2) There is a positive influence of the work environment on the work performance of employees at PT Pura Smart Technology.
\end{abstract}

\begin{abstract}
ABSTRAK
Metode yang digunakan adalah penelitian menggunakan pendekatan kuantitatif dengan kategori penelitian diskriptif. Dalam penelitian survei, informasi dikumpulkan dari responden dengan menggunakan kuesioner. Populasi penelitian ini adalah karyawan yang berjumlah 40 orang sekaligus sebagai sampel yaitu 40 orang karyawan. Pengujian hipotesis pertama $\left(\mathrm{H}_{1}\right)$ diperoleh thitung untuk variabel gaya kepemimpinan sebesar 3,214 dengan signifikansi $0,003(\mathrm{p}<0,05)$. Pengujian hipotesis kedua $\left(\mathrm{H}_{2}\right)$ diperoleh $\mathrm{t}_{\text {hitung }}$ untuk variabel lingkungan kerja sebesar 2,566 dengan signifikansi 0,015 ( $\mathrm{p}<0,05)$. Pengujian hipotesis ketiga $\left(\mathrm{H}_{3}\right)$ diperoleh thitung untuk variabel sistim kompensasi sebesar 3,948 dengan signifikansi 0,000 ( $\mathrm{p}<0,05$ ). Hasil penelitian menunjukkan bahwa, (1) Terdapat pengaruh positif gaya kepemimpinan terhadap prestasi kerja karyawan di PT Pura Smart Tecnology, yang berarti semakin tinggi atau baik gaya kepemimpinan maka semakin tinggi pula prestasi kerja karyawan, sebaliknya semakin rendah atau buruk gaya kepemimpinan maka semakin rendah prestasi kerja karyawan di PT Pura Smart Tecnology. Besarnya sumbangan efektif gaya kepemimpinan terhadap prestasi kerja karyawan di PT Pura Smart Tecnology sebesar $22,7 \%$ dan sumbangan relatif sebesar 32,2\%.(2) Terdapat pengaruh positif lingkungan kerja terhadap prestasi kerja karyawan di PT Pura Smart Tecnology.
\end{abstract}




\section{Buletin Ekonomi}

Kata Kunci : Gaya kepemimpinan, Kompensasi, Lingkungan kerja.

\section{PENDAHULUAN}

Kenyataan yang didapati saat dilakukan pra observasi terhadap perusahaan PT Pura, ditemukan fakta bahwa perusahaan ini menggunakan sistem kemitraan usaha untuk para karyawannya. Sehingga menurut karyawan muncul permasalahan dimana hubungan antara manajer dan karyawan kurang berjalan dengan baik. Hal ini dikarenakan faktor gaya kepemimpinan dari manajer yang membuat keputusan yang kadang sepihak dan kurangnya sosialisasi terhadap suatu keputusan yang dibuat. Keputusan yang kurang sosialisasi akan berakibat fatal terhadap prestasi kerja dari para karyawan.

Menurut persepsi karyawan kepemimpinan yang baik harus dapat memposisikan keputusan yang diterima dan dijalankan oleh semua karyawan dalam perusahaan yang dipimpinnya. Pada berbagai bidang khususnya kehidupan berorganisasi, faktor manusia merupakan masalah utama disetiap kegiatan yang ada didalamnya. Sementara itu untuk melakukan seluruh kegiatan operasional perusahaan, maka diperlukan sumber daya manusia. Sumber daya manusia merupakan salah faktor penting produksi dalam menentukan keberasilan perusahaan. Dalam hal ini diperlukan pengetahuan tentang bagaimana mengarahkan karyawan agar bekerja dengan semaksimal mungkin. Untuk mencapai tujuan tersebut diperlukan karyawan yang terampil, berprestas, professional dan tanggap akan kebutuhan perusahaan. Perusahaan yang siap berkompetisi harus memiliki manajemen yang efektif. Untuk meningkatkan prestasi kerja karyawan dalam manajemen yang efektif memerlukan dukungan karyawan yang cakap dan kompeten di bidangnya. Di sisi lain pembinaan para karyawan termasuk yang harus diutamakan sebagai aset utama perusahaan. Proses belajar harus menjadi budaya perusahaan sehingga keterampilan para karyawan dapat dipelihara, bahkan dapat ditingkatkan. Dalam hal ini loyalitas karyawan yang kompeten harus diperhatikan.

Usaha untuk meningkatkan prestasi kerja karyawan seyogyannya dimotori oleh seorang manajer. Manajer tersebut harus memiliki kemampuan dalam menjalankan gaya kepemimpinan, dimana gaya kepemimpinan pada dasarnya adalah kemampuan dalam untuk mempengaruhi, menggerakan, dan mengarahkan suatu tindakan pada diri seseorang atau kelompok orang untuk tujuan tertentu, Fuad Mas'ud, (2002). Dengan demikian, seorang manajer yang menjalankan gaya kepemimpinan juga harus mempengaruhi bawahannnya untuk melakukan kegiatan yang dapat mendukung pencapaian tujuan organisasi, salah satunya dengan meningkatkan prestasi kerja.

Organisasi yang berhasil adalah yang secara efektif dan efisien mengkombinasikan sumber dayanya guna menerapkan strategi- strateginya. Seberapa baik organisasi memperoleh, mengembangkan, memelihara dan mempertahankan sumber- sumber daya manusianya merupakan determinan utama keberhasilan dan kegagalannya. Secara umum karyawan bekerja karena ada dorongan akan pemenuhan kebutuhan hidupnya. Sehingga para karyawan akan semakin bersemangat bekerja bilamana hasil dari pekerjaanya memperoleh Imbalan (reward) yang sepadan dengan apa yang pekerja tersebut berikan kepada perusahaan.

Selain memberikan imbalan perusahaan perlu juga memberikan tindakan hukuman (punishment). Hukuman (punishment) diberikan kepada karyawan agar karyawan tidak melakukan kesalahan yang merugikan perusahaan. Juga diharapkan dengan adanya punishment ini dapat menjaga prestasi kerja karyawan tetap baik. Sehingga karyawan dapat berprestasi dalam pekerjaannya. Hasil kerja karyawan ini merupakan suatu proses bekerja dari seseorang dalam mengasilkan suatu barang atau jasa. 


\section{Buletin Ekonomi}

Prestasi kerja dari seorang karyawan kadang kala menurun dikarenakan beberapa kemungkinan. Peran gaya kepemimpinan manajer dalam meningkatkan semangat kerja karyawan dengan memberikan motivasi sangat diperlukan. Siagian (2001) berpendapat bahwa pemimpinlah yang bertanggung jawab atas keberhasilan dan kegagalan suatu pekerjaan. Oleh karena itu, pemimpin/ manajer memiliki tanggung jawab untuk memotivasi bawahannya sehingga dapat bekerja dengan giat. Karena karyawan dalam hal ini karyawan perusahaan adalah individu yang memiliki keterbatasan maka peranan manajer dalam menangani masalah dan keterbatasan mereka sangat diperlukan. Untuk meningkatkan prestasi karyawan seorang manajer/ pimpinan memiliki peranan dalam memotivasi kerja karyawan. Sehingga semangat kerja mereka dapat meningkat.

Pengertian prestasi kerja disebut juga sebagai prestasi kerja atau dalam bahasa Inggris disebut dengan performance. (Dessler, 2008) mendefinisikan prestasi kerja yaitu perbandingan antara hasil kerja yang nyata dengan standar kerja yang ditetapkan. Malayu S.P. Hasibuan (2007) Prestasi kerja merupakan hasil kerja yang dicapai seseorang dalam melaksanakan tugas-tugas yang dibebankan kepadanya didasarkan atas kecakapan, pengalaman, kesungguhan dan waktu. Gaya kepemimpinan adalah hubungan yang saling mempengaruhi diantara pemimpin dan pengikut (bawahan) yang menginkan perubahan nyata yang mencerminkan tujuan bersamanya (Rost, 1993 dalam Triantoro Safaria 2004).

Lingkungan kerja juga dapat diartikan keseluruhan sarana dan prasarana kerja yang ada di sekitar karyawan yang sedang melakukan pekerjaan yang dapat mempengaruhi pelaksanaan pekerjaan, lingkungan kerja ini meliputi tempat bekerja, fasilitas, dan alat bantu pekerjaan, kebersihan, pencahayaan, ketenangan, termasuk juga hubungan kerja antara orangorang yang ada di tempat tersebut (Sutrisno 2010: 118). Menurut Hasibuan (2006: 118) Kompensasi adalah semua pendapatan yang berbentuk uang, barang langsung atau tidak langsung yang diterima pegawai sebagai imbalan atas jasa yang diberikan kepada perusahaan.

\section{METODE}

Penelitian ini menggunakan pendekatan kuantitatif dengan kategori penelitian asosiatif kausal. Pendekatan kuantitatif yang digunakan dalam penelitian ini adalah dengan menggunakan metode survei. Populasi penelitian ini adalah karyawan yang berjumlah 40 orang pada PT Pura Smart Tecnology.Jumlah sampel penelitian ini diambil dengan cara melihat tabel Krejcie dan Morgan (1970) dengan tingkat kepercayaan 95\%. Sehingga dari jumlah populasi sebanyak 40 Karyawan maka digunakan populasi selurunya menjadi sample atau 40 orang. Teknik pengambilan sampel untuk menentukan sampel yang akan digunakan dalam penelitian ini menggunakan teknik sampel keseluruhan.

Instrumen dalam penelitian ini menggunakan angket atau kuesioner. Kuesioner merupakan teknik pengumpulan data yang dilakukan dengan cara memberi seperangkat pertanyaan atau pernyataan tertulis kepada responden untuk dijawab Sugiyono (2008:199). Daftar pertanyaan dalam kuesioner ini mencakup permasalahan yang berkaitan dengan kinerja, kedisiplinan, dan disiplin kerja pada karyawan PT Pura Smart Tecnology. Dalam pengukurannya, setiap responden diminta pendapatnya mengenai suatu pernyataan, dengan skala penilaian dari 1 sampai dengan 5. Berdasarkan Skala Likert. Pelaksanaan uji coba kuesioner penelitian harus melalui dua tahapan yang harus dilalui secara berurutan, yaitu: Uji Validitas dan Uji Reliabilitas. Analisis Deskriptif. Uji Prasyarat Analisis (a). Uji Normalitas :1) Hipotesis diterima apabila p value $(\mathrm{Sig})>\quad=0.05$ 2) Hipotesis ditolak apabila $\mathrm{p}$ value $(\mathrm{Sig})<=0.05$ (b). Uji Linieritas (c). Uji Multikolinieritas. Pengujian Hipotesis, Pengujian Hipotesis Secara Simultan (Uji F). 


\section{Buletin Ekonomi}

\section{ANALISIS DAN PEMBAHASAN}

Berdasarkan hasil regresi berganda tersebut diperoleh persamaan regresi berganda sebagai berikut: $\mathrm{Y}=0,678+0,339 \mathrm{X} 1+0,221 \mathrm{X} 2+0,400 \mathrm{X} 3$.

Persamaan regresi tersebut mempunyai makna sebagai berikut:

Konstanta $=0,678$

Jika variabel gaya kepemimpinan, lingkungan kerja dan sistim kompensasi dianggap sama dengan nol, maka variabel prestasi kerja karyawan akan mengalami peningkatan sebesar 0,678 .

Koefisien Gaya Kepemimpinan $(\mathrm{X} 1)=0,339$

Jika variabel gaya kepemimpinan mengalami kenaikan, sedangkan lingkungan kerja dan sistim kompensasi diasumsikan tetap, maka prestasi kerja karyawan akan meningkat sebesar 0,336

Koefisien Lingkungan Kerja $(X 2)=0,221$

Jika variabel lingkungan kerja mengalami kenaikan, sedangkan gaya kepemimpinan dan sistim kompensasi diasumsikan tetap, maka prestasi kerja karyawan akan meningkat sebesar 0,221 .

Koefisien Sistim Kompensasi (X3) $=0,400$

Jika variabel sistim kompensasi mengalami kenaikan, sedangkan gaya kepemimpinan dan lingkungan kerja diasumsikan tetap, maka prestasi kerja karyawan akan meningkat sebesar 0,400 .

Pengujian hipotesis pertama (H1) diperoleh thitung untuk variabel gaya kepemimpinan sebesar 3,214 dengan signifikansi 0,003 ( $\mathrm{p}<0,05$ ). Hasil tersebut menunjukkan bahwa Ho ditolak dan $\mathrm{Ha}$ diterima sehingga $\mathrm{H} 1$ yang menyatakan terdapat pengaruh positif gaya kepemimpinan terhadap prestasi kerja karyawan di PT Pura Smart Tecnology, diterima. Pengujian hipotesis kedua $(\mathrm{H} 2)$ diperoleh thitung untuk variabel lingkungan kerja sebesar 2,566 dengan signifikansi 0,015 ( $\mathrm{p}<0,05)$. Hasil tersebut menunjukkan bahwa Ho ditolak dan Ha diterima sehingga $\mathrm{H} 2$ yang menyatakan pengaruh positif lingkungan kerja terhadap prestasi kerja karyawan di PT Pura Smart Tecnology, diterima. Pengujian hipotesis ketiga (H3) diperoleh thitung untuk variabel sistim kompensasi sebesar 3,948 dengan signifikansi 0,000 ( $\mathrm{p}<0,05$ ). Hasil tersebut menunjukkan bahwa Ho ditolak dan Ha diterima sehingga $\mathrm{H} 3$ yang menyatakan terdapat pengaruh positif sistim kompensasi terhadap prestasi kerja karyawan di PT Pura Smart Tecnology, diterima.

Uji signifikansi dimaksudkan untuk memeriksa keberartian apakah regresi berbentuk linear yang didapat bisa dipergunakan untuk membuat kesimpulan mengenai pertautan sejumlah variabel yang sedang dipelajari. Jika Fhit $>$ Ftabel atau $\mathrm{p}<0,05$ maka dapat dikatakan bahwa hipotesis alternatif diterima dan menunjukkan pengaruh gaya kepemimpinan, lingkungan kerja dan sistim kompensasi terhadap prestasi kerja karyawan di PT Pura Smart Tecnologi. Hasil pengujian secara bersama-sama atau simultan diperoleh nilai $F$ sebesar 28,602 dengan nilai sig. sebesar 0,000 sehingga $p<0,05$ menunjukkan terdapat pengaruh positif secara bersama-sama atau simultan antara gaya kepemimpinan, lingkungan kerja dan sistim kompensasi terhadap prestasi kerja karyawan di PT Pura Smart Tecnology, sehingga Ho ditolak dan Ha diterima maka H4 yang menyatakan terdapat gaya kepemimpinan, lingkungan kerja dan sistim kompensasi terhadap prestasi kerja karyawan di PT Pura Smart Tecnology.

Besarnya pengaruh variabel gaya kepemimpinan, lingkungan kerja dan sistim kompensasi terhadap prestasi kerja karyawan di PT Pura Smart Tecnology. Hasil pengujian determinasi ganda diperoleh nilai $\mathrm{R} 2=0,704$ atau 70,4\% ini berarti variabel bebas gaya kepemimpinan, lingkungan kerja dan sistim kompensasi secara simultan atau bersama-sama 


\section{Buletin Ekonomi}

mempengaruhi variabel dependen prestasi kerja karyawan sebesar 70,4\% dan sisanya sebesar 29,6\% dipengaruhi oleh variabel lain yang tidak diteliti pada penelitian ini.

Uji determinasi parsial digunakan untuk mengetahui seberapa besar sumbangan dari masing-masing variabel bebas terhadap variabel terikat. Secara parsial atau sumbangan efektif (SE) pengaruh gaya kepemimpinan, lingkungan kerja dan sistim kompensasi terhadap prestasi kerja karyawan di PT Pura Smart Tecnology, dapat dilihat pada tabel berikut:

Sumbangan Efektif

Tabel 1.

Sumbangan Efektif

\begin{tabular}{lccc}
\hline \multicolumn{1}{c}{ Variabel Bebas } & Beta & Nilai Korelasi $\left(\mathrm{r}_{\mathrm{xy}}\right)$ & $\begin{array}{c}\text { Sumbangan } \\
\text { Efektif }\end{array}$ \\
\hline Gaya Kepemimpinan $\left(\mathrm{X}_{1}\right)$ & 0,343 & 0,661 & $22,7 \%$ \\
Lingkungan kerja $\left(\mathrm{X}_{2}\right)$ & 0,265 & 0,591 & $15,7 \%$ \\
Sistim kompensasi $\left.\mathrm{X}_{3}\right)$ & 0,439 & 0,731 & $32,1 \%$ \\
\hline & Total & & $70,4 \%$ \\
\hline
\end{tabular}

Sumber : Data primer yang diolah, 2019

Sumbangan efektif sistim kompensasi terhadap prestasi kerja karyawan di PT Pura Smart Tecnologi sebesar 32,1\% lebih besar dibandingkan dengan pengaruh gaya kepemimpinan terhadap prestasi kerja karyawan sebesar $22,7 \%$ dan pengaruh lingkungan kerja terhadap prestasi kerja karyawan sebesar 17,4\%.

Sumbangan relatif (SR) pengaruh gaya kepemimpinan, lingkungan kerja dan sistim kompensasi terhadap prestasi kerja karyawan di PT Pura Smart Tecnology, dapat dilihat pada tabel berikut:

Tabel 2.

Sumbangan Relatif

\begin{tabular}{lcc}
\hline \multicolumn{1}{c}{ Variabel Bebas } & Sumbangan Efektif & $\begin{array}{c}\text { Sumbangan } \\
\text { Relatif }\end{array}$ \\
\hline Gaya Kepemimpinan $\left(\mathrm{X}_{1}\right)$ & $22,7 \%$ & $32,2 \%$ \\
Lingkungan kerja $\left(\mathrm{X}_{2}\right)$ & $15,7 \%$ & $22,2 \%$ \\
Sistim kompensasi $\left.\mathrm{X}_{3}\right)$ & $32,1 \%$ & $45,6 \%$ \\
\hline \multicolumn{1}{c}{ Total } & $70,4 \%$ & $100,0 \%$ \\
\hline
\end{tabular}

Sumber : Data primer yang diolah, 2019

Berdasarkan tabel diketahui besarnya sumbangan relatif sistim kompensasi terhadap prestasi kerja karyawan di PT Pura Smart Tecnologisebesar 45,6\% lebih besar dibandingkan dengan pengaruh gayakepemimpinan terhadap prestasi kerja karyawan sebesar 32,2\% dan pengaruh lingkungan kerja terhadap prestasi kerja karyawan sebesar 22,3\%. Jadi dapat diambil kesimpulan bahwa sistim kompensasi mempunyai pengaruh yang paling besar terhadap prestasi kerja karyawan, sedangkan lingkungan kerja mempunyai pengaruh yang paling kecil terhadap prestasi kerja karyawan.

Pengujian hipotesis pertama (H1) menunjukkan terdapat pengaruh positif gaya kepemimpinan terhadap prestasi kerja karyawan di PT Pura Smart Tecnologi $(t=3,243$ dan $p$ $<0,05)$. Hal ini berarti semakin tinggi atau baik gaya kepemimpinan maka semakin tinggi pula prestasi kerja karyawan, sebaliknya semakin rendah atau buruk gaya kepemimpinan maka semakin rendah prestasi kerja karyawan di PT Pura Smart Tecnology. Besarnya sumbangan efektif gaya kepemimpinan terhadap prestasi kerja karyawan di PT Pura Smart Tecnology sebesar $22,7 \%$ dan sumbangan relatif sebesar $32,2 \%$. 


\section{Buletin Ekonomi}

Selain itu, pemimpin betransaksi dengan bawahan, dengan memfokuskan pada aspek kesalahan yang dilakukan bawahan, menunda keputusan atau menghindari hal-hal yang kemungkinan mempengaruhi terjadinya kesalahan. Management by-exception menekankan fungsi managemen sebagai kontrol. Pimpinan hanya melihat dan mengevaluasi apakah terjadi kesalahan untuk diadakan koreksi, pimpinan memberikan intervensi pada bawahan apabila standar tidak dipenuhi oleh bawahan. Praktik management by-exception, pimpinan mendelegasikan tanggungjawab kepada bawahan dan menindaklanjuti dengan memberikan apakah bawahan dapat berupa pujian untuk membesarkan hati bawahan dan juga dengan hadiah apabila laporan yang dibuat bawahan memenuhi standar. Menurut Bycio dkk. (1995, dalam Dwi Ari Wibawa) gaya kepemimpinan transaksional adalah gaya gaya kepemimpinan di mana seorang pemimpin menfokuskan perhatiannya pada transaksi interpersonal antara pemimpin dengan karyawan yang melibatkan hubungan pertukaran. Pertukaran tersebut didasarkan pada kesepakatan mengenai klasifikasi sasaran, standar kerja, penugasan kerja, dan penghargaan.

Masalah Unsur- unsur penilaian kerangka kerja di bawah ini menyajikan gambaran untuk mengarahkan tujuan penelitian ini. Dimana kerangka penilitian ini merupakan pengembangan dari kerangka pemikiran dari penilitian sebelumnya.

Pengujian hipotesis kedua (H2) menunjukkan terdapat pengaruh positif lingkungan kerja terhadap prestasi kerja karyawan di PT Pura Smart Tecnologi $(\mathrm{t}=2,566$ dan $\mathrm{p}<0,05)$. Hal ini berarti semakin tinggi atau baik lingkungan kerja maka semakin tinggi pula prestasi kerja karyawan, sebaliknya semakin rendah atau buruk lingkungan kerja maka semakin rendah pula prestasi kerja karyawan di PT Pura Smart Tecnology. Besarnya sumbangan efektif lingkungan kerja terhadap prestasi kerja karyawan di PT Pura Smart Tecnology. sebesar $15,7 \%$ dan sumbangan relatif sebesar $22,3 \%$.

Hasil ini sejalan dengan penelitian Menurut Burns (1978 dalam Dwi Ari Wibawa) pada gaya kepemimpinan transaksional, hubungan antara pemimpin dengan bawahan didasarkan pada serangkaian aktivitas tawar menawar antar keduanya. Karakteristik gaya kepemimpinan transaksional adalah contingent reward dan management byexception. Pada contingent reward dapat berupa penghargaan dari pimpinan karena tugas telah dilaksanakan, berupa bonus atau bertambahnya penghasilan atau fasilitas. Hal ini dimaksudkan untuk memberi penghargaan maupun pujian untuk bawahan terhadap upaya-upayanya.

Pengujian hipotesis ketiga (H3) menunjukkan terdapat pengaruh positif sistim kompensasi terhadap prestasi kerja karyawan di PT Pura Smart Tecnologi $(\mathrm{t}=3,948$ dan $\mathrm{p}<$ 0,05). Hal ini berarti semakin tinggi sistim kompensasi maka semakin tinggi pula prestasi kerja karyawan, sebaliknya semakin rendah sistim kompensasi maka semakin rendah pula prestasi kerja karyawan di PT Pura Smart Tecnology. Besarnya sumbangan efektif sistim kompensasi terhadap prestasi kerja karyawan di PT Pura Smart Tecnology. sebesar 32,1\% dan sumbangan relatif sebesar $45,6 \%$.

Selain itu, pemimpin betransaksi dengan bawahan, dengan memfokuskan pada aspek kesalahan yang dilakukan bawahan, menunda keputusan atau menghindari hal-hal yang kemungkinan mempengaruhi terjadinya kesalahan. Management by-exception menekankan fungsi managemen sebagai kontrol. Pimpinan hanya melihat dan mengevaluasi apakah terjadi kesalahan untuk diadakan koreksi, pimpinan memberikan intervensi pada bawahan apabila standar tidak dipenuhi oleh bawahan. Praktik management by-exception, pimpinan mendelegasikan tanggungjawab kepada bawahan dan menindaklanjuti dengan memberikan apakah bawahan dapat berupa pujian untuk membesarkan hati bawahan dan juga dengan hadiah apabila laporan yang dibuat bawahan memenuhi standar. Kemudian menurut Bycio dkk. (1995, dalam Dwi Ari Wibawa) gaya kepemimpinan transaksional adalah gaya gaya kepemimpinan di mana seorang pemimpin menfokuskan perhatiannya pada transaksi 


\section{Buletin Ekonomi}

interpersonal antara pemimpin dengan karyawan yang melibatkan hubungan pertukaran. Pertukaran tersebut didasarkan pada kesepakatan mengenai klasifikasi sasaran, standar kerja, penugasan kerja, dan penghargaan.

Pengujian hipotesis keempat (H4) menunjukkan terdapat pengaruh positif gaya kepemimpinan, lingkungan kerja dan sistim kompensasi terhadap prestasi kerja karyawan di PT Pura Smart Tecnologi $(F=28,602$ dan $p<0,05)$. Besarnya sumbangan efektif secara simultan pengaruh positif gaya kepemimpinan, lingkungan kerja dan sistim kompensasi terhadap prestasi kerja karyawan di PT Pura Smart Tecnologisebesar 70,4\% dan sisanya sebesar 29,6\% dipengaruhi faktor lain di luar variabel bebas pada penelitian ini.

Prestasi kerja karyawan merupakan prestasi yang diraih atas keberhasilan karyawan dalam menjalankan tugas dan tanggung jawabnya berdasarkan dengan standar/aturan yang telah ditetapkan sesuai dengan kompetensi yang dimilikinya untuk mencapai tujuan yang diharapkan. Karyawan sebagai ujung tombak dalam pendidikan harus bisa menunjukkan prestasi kerja yang baik dalam melaksanakan tugas dan tanggung jawabnya.

Selain itu, pemimpin betransaksi dengan bawahan, dengan memfokuskan pada aspek kesalahan yang dilakukan bawahan, menunda keputusan atau menghindari hal-hal yang kemungkinan mempengaruhi terjadinya kesalahan. Management by-exception menekankan fungsi managemen sebagai kontrol. Pimpinan hanya melihat dan mengevaluasi apakah terjadi kesalahan untuk diadakan koreksi, pimpinan memberikan intervensi pada bawahan apabila standar tidak dipenuhi oleh bawahan. Praktik management by-exception, pimpinan mendelegasikan tanggungjawab kepada bawahan dan menindaklanjuti dengan memberikan apakah bawahan dapat berupa pujian untuk membesarkan hati bawahan dan juga dengan hadiah apabila laporan yang dibuat bawahan memenuhi standar.

Sementara itu menurut Bycio dkk. (1995, dalam Dwi Ari Wibawa) gaya kepemimpinan transaksional adalah gaya gaya kepemimpinan di mana seorang pemimpin menfokuskan perhatiannya pada transaksi interpersonal antara pemimpin dengan karyawan yang melibatkan hubungan pertukaran. Pertukaran tersebut didasarkan pada kesepakatan mengenai klasifikasi sasaran, standar kerja, penugasan kerja, dan penghargaan. Masalah Unsur- unsur penilaian kerangka kerja di bawah ini menyajikan gambaran untuk mengarahkan tujuan penelitian ini. Dimana kerangka penilitian ini merupakan pengembangan dari kerangka pemikiran dari penilitian sebelumnya.

Jadi jelaslah bahwa dalam penelitian ini faktor yang mempengaruhi prestasi kerja karyawan ada dua macam yaitu faktor internal dan faktor eksternal. Faktor internal adalah faktor yang datang dari dalam diri karyawan yang dapat mempengaruhi prestasi kerjanya, contohnya antara lain adalah kemampuan, keterampilan, kepribadian, persepsi, motivasi menjadi karyawan, pengalaman lapangan, dan latar belakang keluarga. Sedangkan faktor eksternal prestasi kerja karyawan adalah faktor yang datang dari luar karyawan yang dapat mempengaruhi prestasi kerjanya, antara lain lingkungan kerja dan kepemimpinan.

\section{KESIMPULAN}

Berdasarkan temuan-temuan penelitian seperti yang diuraikan pada bab sebelumnya, maka diambil simpulan sebagai berikut: (1) Terdapat pengaruh positif dan signifikan antara gaya kepemimpinan terhadap prestasi kerja karyawan di PT Pura Smart Tecnology, yang berarti semakin tinggi atau baik gaya kepemimpinan maka semakin tinggi pula prestasi kerja karyawan, sebaliknya semakin rendah atau buruk gaya kepemimpinan maka semakin rendah prestasi kerja karyawan di PT Pura Smart Tecnology. Besarnya sumbangan efektif gaya kepemimpinan terhadap prestasi kerja karyawan di PT Pura Smart Tecnology sebesar 22,7\% dan sumbangan relatif sebesar $32,2 \%$. (2) Terdapat pengaruh positif dan signifikan antara lingkungan kerja terhadap prestasi kerja karyawan di PT Pura Smart Tecnology, yang berarti 


\section{Buletin Ekonomi}

semakin tinggi atau baik lingkungan kerja maka semakin tinggi pula prestasi kerja karyawan, sebaliknya semakin rendah atau buruk lingkungan kerja maka semakin rendah pula prestasi kerja karyawan di PT Pura Smart Tecnology. Besarnya sumbangan efektif lingkungan kerja terhadap prestasi kerja karyawan di PT Pura Smart Tecnologysebesar 15,7\% dan sumbangan relatif sebesar 22,3\%. (3) Terdapat pengaruh positif dan signifikan antara sistim kompensasi terhadap prestasi kerja karyawan di PT Pura Smart Tecnology Hal ini berarti semakin tinggi sistim kompensasi maka semakin tinggi pula prestasi kerja karyawan, sebaliknya semakin rendah sistim kompensasi maka semakin rendah pula prestasi kerja karyawan di PT Pura Smart Tecnology. Besarnya sumbangan efektif sistim kompensasi terhadap prestasi kerja karyawan di PT Pura Smart Tecnology sebesar 32,1\% dan sumbangan relatif sebesar 45,6\%. (4) Terdapat pengaruh positif dan signifikan antara gaya kepemimpinan, lingkungan kerja dan sistim kompensasi secara bersama-sama terhadap prestasi kerja karyawan di PT Pura Smart Tecnology. Besarnya sumbangan efektif secara simultan pengaruh positif gaya kepemimpinan, lingkungan kerja dan sistim kompensasi terhadap prestasi kerja karyawan di PT Pura Smart Tecnologisebesar 70,4\% dan sisanya sebesar 29,6\% dipengaruhi faktor lain di luar variabel bebas pada penelitian ini.

Berdasarkan hasil penelitian ini maka dikemukakan beberapa saran, yaitu: Pimpinan atau manajer perusahaan hendaknya dapat meningkatkan memilih gaya kepemimpinan yang sesuai dengan lingkungannya, dimana Pimpinan atau manajer perusahaan harus bersikap adil dan bijaksana terhadap semua karyawan dan staf di perusahaan. Pimpinan atau manajer perusahaan bersikap tidak membeda-bedakan antara karyawan satu dengan karyawan lainnya, atau tidak ada karyawan yang menjadi anak emas sehingga karyawan meraakan sikap dan perlakuan yang sama oleh Pimpinan atau manajer perusahaan. Selain itu Pimpinan atau manajer perusahaan memberikan penghargaan yang sesuai dengan hasil yang dicapai atau prestasi kerja dari masing-masing karyawan dan memberi kesempatan pada karyawan untuk mengembangkan potensi yang dimiliki dengan memberikan ijin belajar ke jenjang yang lebih tinggi atau mengikuti pelatihan-pelatihan sebagai wujud untuk meningkatkan profesionalitasnya sebagai seorang karyawan.

Karyawan dapat memiliki integritas kepribadian, maka akan melakukan sesuatu yang sesuai antara apa yang diucapkan dan apa yang dilakukan. Bekerja tidak semata untuk meraih prestasi duniawi tetapi juga memiliki makna ibadah.

Kemudian bagi penelitia lain agar hasil analisis lebih luas cakupannya maka penelitian yang akan datang perlu diteliti lanjut untuk aspek yang lebih beragam dan obyek studi yang lebih luas mengingat PT Pura Smart Tecnology merupakan bagian dari grup yang besar.

\section{DAFTAR PUSTAKA}

Ariwibowo, Dwi Putra Jati dan Mahendra Adhi Nugroho 2013. Pengaruh Trust Dan Perceived of Risk Terhadap Niat Untuk Bertransaksi Menggunakan Ecommerce. Jurnal Nominal. Vol. 02, No. 01, 2013.

Bafadal. 2003. Peningkatan Profesioalisme Karyawan Perusahaan Dasar. Jakarta : Bumi Aksara.

Bernardin, H.John and Russel. 2010. Human Resource Management. New York: McGrawHill

Burns, J.M. 1978. Leadership. Harper \& Row. New York, NY.

Cahyani, N dan Ardana, K. 2013. Pengaruh Lingkungan Kerja Fisik, Gaya Kepemimpinan dan Insentif Finansial terhadap Kinerja Pegawai Non Medis pada Rumah Sakit Balimed Denpasar. E-Jurnal Manajemen Universitas Udayana, 2 (4), 423-435. 


\section{Buletin Ekonomi}

Daft, Richard L. 2007 Manajemen Edisi 1, Alih bahasa oleh Edward Tanujaya dan Shirly Tiolina. Salemba Empat, Jakarta,

Darodji, Ahmad. 2002. Pengaruh Motivasi, Kepemimpinan dan Kemampuan Terhadap Prestasi Kerja Pegawai Lain. Semarang, Diros Pustaka.

Dessler, G. 2008. Human Resource Management. 11th Edition, New Jersey: Pearson Education.

Gomes, Faustino Cardoso. 2003. Manajemen Sumber Daya Manusia, Yogyakarta: Perbit Andi

Hadari Nawawi.2005.Penelitian Terapan.Yogyakarta:Gajah Mada University Press.

Hameed. 2014. Impact of Compensation on Employee Performance (Empirical Evidence from Banking Sector Pakistan). International Journal of Business and Social Science Vol. 5 No. 2

Hasibuan, Malayu S.P. 2007. Manajemen Sumber Daya Manusia. Jakarta : Penerbit Bumi Aksara.

Hasibuan, Malayu, S.P. 2006. Manajemen Sumber Daya Manusia, PT. Gunung Agung. Jakarta.

Hasibuan, Malayu. S.P. 2003. Manajemen Dasar, Pengertian dan Masalah. PT. Toko Gunung Agung : Jakarta.

Karyawannto, Bejo. 2005. Manajemen Tenaga Kerja Indonesia Pendekatan Administratif dan Operasional. Bumi Aksara : Jakarta

Mas'ud, Fuad. 2002, 40 Mitos Manajemen Sumber Daya Manusia : Badan Penerbit Universitas Diponegoro, Semarang.

Moleong, L.J. 2011. Metodologi Penelitian Kualitatif Edisi Revisi. Bandung: PT

Mangkunegara, 2005. Perencanaan dan Pengembangan Manajemen Sumber Daya Manusia Perusahaan, PT. Remaja Rosdakarya, Bandung.

Miftah. 2004. Gaya kepemimpinan dalam Manajemen. PT. Raja Grafindo Persada : Jakarta.

Moedjiman. 2007. Berita Pasar Kerja Depnaker. Gunung Agung : Jakarta.

Moleong, Lexy J, 2004, Metodologi Penelitian Kualitatif, Edisi revisi PT. Remaja Rosdakarya : Bandung.

Nitisemito, Alex S, 2002, Manajemen Personalia. Cetakan ke 9. Edisi ke 4. Jakarta: Ghalia Indonesia.

Norianggono, Hamid dan Ika Ruhana. 2014. "Pengaruh Lingkungan Kerja Fisik dan Non Fisik Terhadap Kinerja Karyawan (Studi Pada Karyawan PT. Telkomsel Area III JawaTengah Nusra di Surabaya)"

Prawirosentono, Suyadi. 2002. Manajemen Sumber Daya Manusia: Kebijakan Prestasi kerja Karyawan. Edisi 1. Cetakan Kedelapan. BPFE. Yogyakarta

Rivai, Veithzal \& Ahmad Fawzi Mohd. Basri. 2005. Performance Appraisal: Untuk Sistem Yang Tepat Untuk Menilai Prestasi kerja Karyawan dan Meningkatkan Daya Saing Perusahaan. Jakarta: PT. Raja Grafindo Persada 


\section{Buletin Ekonomi}

Iswanto Sastrohadiwiryo. 2003. Manajemen Tenaga Kerja Indonesia, Pendekatan Administrasi dan Operasional. Jakarta: Bumi Aksara.

Sastrohadiwiryo, Karyawannto. 2001. Manajemen Tenaga kerja Indonesia, Pendekatan Administratif dan Operasional. Jakarta : Bumi Aksara.

Sedarmayanti. 2001. Sumber Daya Manusia dan Prestasi Kerja. Ilham Jaya. Bandung.

Siagian P. Sondang.2003 kiat meningkatkan Prestasi kerja. PT Asdi Mahasatya : Jakarta. Remaja Rosdakarya.

Sugiyono. 2008. Metode Penelitian Administrasi. Bandung : CV Alfabeta

Sugiyono. 2009. Metode Penelitian Administrasi. Bandung : CV Alfabeta

Sumartiningsih 2008 Pengaruh Kompetensi Profesional dan Iklim Organisasi ter hadap Kinerja Dosen Akademi Keperawatan Budi Luruh Cimahi. Jurnal USU

Suwarni 2008 Pengaruh Kecerdasan Emosional, Kompetensi dan Motivasi Kerja terhadap Kinerja Dosen di Program Studi Ilmu Keperawatan Universitas Sahid Surakarta.Jurnal USU

Sutrisno, 2010. Manajemen Sumber Daya Manusia. Jakarta : Kencana

Siwantara 2009 Pengaruh Kompetensi Profesi onal dan Motivasi Kerja serta Iklim Organisasi terhadap Disiplin Kerja dan Kinerja Dosen Politeknik Negeri Bali.Jurnal USU

Suntora 2009 Pengaruh Budaya Organisasi, Kepemimpinan, Kepuasan Kerja Terhadap Prestasi kerja Dosen FKIP Universitas Lampung.Jurnal USU.

Sutrisno, Hadi 2001. Metodologi Research Jilid II. Yogyakarta: Andi

Sondang P. Siagian, 2001, "Manajemen Sumber Daya Manusia", Bumi Aksara, Jakarta.

Sughanda, Dann, 2009. Pengantar Administrasi Negara, Intermedia : Jakarta

Sugiyono. 2004, Metode Penelitian Administrasi. Alfabeta : Bandung. Thoha,

Triantoro, Safaria. 2004. “Kepemimpinan”. Edisi Pertama. Graha Ilmu, Yogyakarta.

Wahjosumidji. 2012. Gaya kepemimpinan Dan Motivasi, Ghalia Indoensia : Jakarta.

Winardi, 2011. Evaluasi Prestasi kerja Sumber Daya Manusia. Salemba Empat : Jakarta. 